\title{
Developmental Regulation of Angiotensinogen Gene Expression in Sheep
}

\author{
ANN LOUISE OLSON, STANLEY PERLMAN, AND JEAN E. ROBILLARD
}

Department of Pediatrics, University of Iowa, College of Medicine, Iowa City, Iowa 52242

\begin{abstract}
It has been suggested that the liver is not the main source of angiotensinogen during fetal life in rats, but that the kidney is an important site of fetal angiotensinogen synthesis. In an effort to determine if this phenomenon is specific to the rat or applicable to other species, we compared the ontogenic changes in hepatic and renal angiotensinogen mRNA expression in fetal $(60,90,118$, and $138 \mathrm{~d}$ of gestation, term being $145 \mathrm{~d}$ ), newborn ( $7 \mathrm{~d}$ postnatal), and adult sheep. Total RNA was extracted, subjected to Northern blotting and hybridized using a fulllength rat radiolabeled antisense RNA. Angiotensinogen mRNA sequences were detected in all fetal liver samples and appeared to increase 3-fold from 60 to $138 \mathrm{~d}$ gestation and then to decrease after birth. In contrast, angiotensiogen mRNA could not be detected in renal cortical tissue of 118 or $138 \mathrm{~d}$ fetuses, or newborn or adult sheep. We conclude that, unlike in the rat, liver angiotensinogen gene expression is detectable during the 2nd trimester of gestation in sheep and is developmentally regulated. Furthermore, in contrast to the fetal rat, angiotensinogen mRNA sequences were undetectable in fetal sheep kidney. (Pediatr Res 28: 183-185, 1990)
\end{abstract}

\section{Abbreviations}

SSPE, 0.18 M NaCl, 10 mM NaPO 4 pH 7.7, 1 mM EDTA

The existence of a functional renin-angiotensin system during fetal life has been documented (1) and developmental aspects of this system have been recently reviewed (2). It has been shown that fetal plasma levels of renin, angiotensinogen, angiotensin I, and angiotensin II are elevated when compared with adult values (3), and that the kidney is the primary source of circulating renin in near-term fetus (4), as it is in the adult.

It has also been demonstrated that the primary source of angiotensinogen synthesis in the adult is the liver (5). On the other hand, recent studies by Gomez et al. (6) suggest that the liver may not be the main source of angiotensinogen during fetal life, but that the kidney and possibly brown fat and brain are also important sites of angiotensinogen synthesis in the fetal rat. Interestingly, they have also observed that the expression of liver angiotensinogen increases rapidly in the first $24 \mathrm{~h}$ after birth in the rat, suggesting that the developmental regulation of angiotensinogen is tissue-specific.

In an effort to determine if this phenomenon is specific to the rat or applicable to other species, we compared the ontogenic

Received January 18, 1990; accepted April 16, 1990.

Correspondence: Ann Louise Olson, PhD, Department of Pediatrics, University of lowa, Iowa City, IA 52242.

Supported by NIH Grants HD-20576, DK-38302, HL-35600, HL-14388, and NS.24401. A.L.O, was supported by a National Research Service Award, HL 08010. S.P. was supported by a Research Career Development Award from the National Institutes of Health. changes in hepatic and renal angiotensinogen gene expression during the last trimester of gestation in fetal sheep. We demonstrated that, unlike in the rat, hepatic angiotensinogen gene expression in sheep is detectable early during the last trimester of gestation and increases as the fetus approaches birth. Furthermore, in contrast to the rat, renal angiotensinogen mRNA sequences were undetectable in fetal sheep.

\section{MATERIALS AND METHODS}

Animals. Pregnant mixed-breed Dorset-Suffolk ewes and newborn lambs ( $7 \mathrm{~d}$ postnatal) were obtained from a local source; the gestational age was known based on the induced-ovulation technique (7). Pregnant ewes were anesthetized with a mixture of $1.0-1.5 \%$ halothane, $33 \%$ oxygen, and $66 \%$ nitrous oxide given by an endotracheal tube (8). The uterus was exteriorized to gain access to fetuses. Liver and kidney cortex samples were obtained from fetuses at $60,90,118$, and $138 \mathrm{~d}$ gestation, term being $145 \mathrm{~d}$. Newborn lambs were similarly anesthetized before tissue harvest. All procedures were approved by the University of Iowa Animal Care and Use Committee.

$R N A$ isolation. RNA was isolated using a minor modification of the guanidinium isothiocyanate- $\mathrm{CsCl}$ method of Chirgwin et al. (9). With our modification, $0.5 \mathrm{~g}$ of fresh tissue was homogenized in $5 \mathrm{M}$ guanidinium isothiocyanate in a buffer consisting of $30 \mathrm{mM} \mathrm{Na}$ acetate buffer, pH 5.2, $10 \mathrm{mM}$ EDTA, pH 5.0, $0.2 \%$ sarcosyl, and $5.0 \%$ 2-mercaptoethanol. $\mathrm{CsCl}$ was added to the tissue homogenate at a final concentration of $0.4 \mathrm{~g} / \mathrm{mL}$, and this mixture was layered over a cushion of $5.7 \mathrm{M} \mathrm{CsCl}, 30 \mathrm{mM}$ $\mathrm{Na}$ acetate buffer, pH 5.2, $10 \mathrm{mM}$ EDTA. The RNA was pelleted by centrifugation at $35000 \mathrm{rpm}$ for $16 \mathrm{~h}$ at $20^{\circ} \mathrm{C}$. The RNA pellet was purified by extraction with chloroform:butanol and ethanol precipitated in the presence of $0.3 \mathrm{M} \mathrm{Na}$ acetate buffer, pH 5.2. RNA was quantified spectrophotometrically by absorbance at $260 \mathrm{nM}$. RNA samples were stored as an ethanol precipitate at $-70^{\circ} \mathrm{C}$ until further analysis.

Preparation of probes. A clone containing full-length rat angiotensinogen cDNA (pRang 6) (10) was obtained from K. R. Lynch. This cDNA, when linearized with EcoRI, yields the antisense mRNA upon transcription from the T7 promoter. A 2.0 -kb fragment of $\beta$-actin cDNA (11) that had been subcloned into pSP18 (Promega, Madison, WI) as described (12) was obtained from P. Rubenstein. After linearization of this plasmid with EcoRI, transcription from the SP6 promoter yields the antisense mRNA. ${ }^{32} \mathrm{P}$-labeled antisense mRNA were transcribed according to the method of Melton et al. (13) using $\alpha-{ }^{32} \mathrm{P}$-uridine triphosphate (Amersham Corp., Arlington Heights, IL).

Northern blot hybridization. Aliquots of 5 or $10 \mu \mathrm{g}$ of RNA as measured by absorbance at $260 \mathrm{~nm}$ were fractionated by $1 \%$ agarose-formaldehyde gel electrophoresis (14). After electrophoresis, RNA was transferred to Nytran filters, $0.45 \mu \mathrm{m}$ (Schleicher and Schuell Inc., Keene, NH). The filters were prehybridized for $1 \mathrm{~h}$ at $60^{\circ} \mathrm{C}$ in a solution of $50 \%$ deionized formamide, $5 \times$ SSPE, $5 \times$ Denhardt's reagent, $1.0 \%$ SDS and $200 \mu \mathrm{g} / \mathrm{mL}$ denatured fractionated salmon sperm DNA. Hybridization of 
filters with either ${ }^{32} \mathrm{P}$-labeled angiotensinogen or $\beta$-actin mRNA was done with fresh prehybridization buffer solution containing $1 \times 10^{6} \mathrm{cpm} / \mathrm{mL}$ of the appropriate radio-labeled probe. The hybridization reaction was carried out at $60^{\circ} \mathrm{C} 12-18 \mathrm{~h}$.

Filters were washed according to manufacturer's specifications. Briefly, this included three low-stringency washes $(1 \times$ SSPE, $1.0 \% \mathrm{SDS})$ at $65^{\circ} \mathrm{C}$ and a high stringency wash $(0.1 \times \mathrm{SSPE}$, $1.0 \% \mathrm{SDS}$ ) at $60^{\circ} \mathrm{C}$ followed by treatment with ribonuclease $\mathrm{A}$ $(10 \mu \mathrm{g} / \mathrm{mL}$ in $2 \times \mathrm{SSPE})$ at $37^{\circ} \mathrm{C}$ for $15 \mathrm{~min}$. The washed filters were exposed to Kodak XAR film at $-70^{\circ} \mathrm{C}$.

The autoradiographs from Northern blots were quantitated using a Soft Laser scanning densitometer, model SLR-2D10 (Biomed Instruments, Inc., Fullerton, CA). Results of separate Northern blots were normalized by calculating all bands to a single $138 \mathrm{~d}$ fetus sample, which was run on each Northern blot. This band was considered $100 \%$ expression. All data were subsequently expressed as a percent of this sample. Individual liver samples were analyzed in duplicate or triplicate and the mean value for each analysis was then used to calculate the grand mean for livers within each age group. Age-related changes in angiotensinogen mRNA expression were analyzed by one-way analysis of variance (15).

\section{RESULTS}

Changes in the level of angiotensinogen mRNA in the liver of fetal sheep are shown in Figure 1. Using Northern blot hybridization, we observed a progressive increase in hepatic angiotensinogen mRNA during gestation. Moreover, the size of the angiotensinogen message did not appear to change during gestation. Among the fetal and newborn sheep, it appeared that the highest level of liver angiotensinogen mRNA was expressed in the nearterm fetuses. In contrast, duplicate samples of RNA analyzed for $\beta$-actin mRNA expression (Fig. 2) showed no changes with gestation. Quantitation of angiotensinogen and $\beta$-actin mRNA is summarized in Table 1 . These results, expressed as percent of angiotensinogen mRNA present in 138-d fetuses, show that angiotensinogen mRNA increases about 3-fold from 60 to 138 $\mathrm{d}$ gestation, whereas there was no significant change in $\beta$-actin mRNA. This suggests that the developmental changes seen in

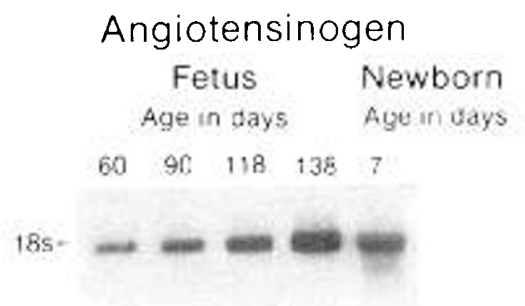

Fig. 1. Autoradiograph of Northern blot analysis of fetal and newborn liver RNA. Five- $\mu \mathrm{g}$ aliquots of total cellular RNA were fractionated by gel electrophoresis and transferred to a nylon filter. The Northern blot was hybridized with ${ }^{32} \mathrm{P}$-labeled antisense angiotensinogen RNA. The hybridized filter was exposed to film for $48 \mathrm{~h}$.

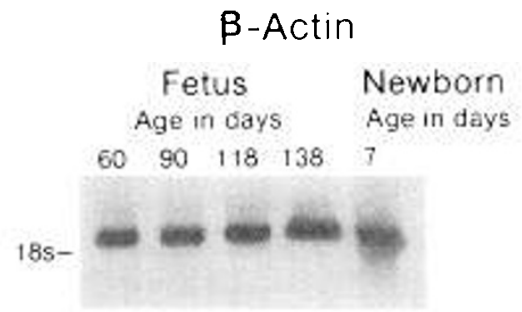

Fig. 2. Autoradiograph of Northern blot analysis of fetal and newborn liver RNA. Five- $\mu$ g aliquots of total cellular RNA were fractionated by gel electrophoresis and transferred to a nylon filter. The Northern blot was hybridized with ${ }^{32} \mathrm{P}$-labeled antisense $\beta$-actin RNA. The hybridized filter was exposed to film for $2 \mathrm{~h}$.
Table 1. Percent of angiotensinogen and $\beta$-actin $m R N A$ in fetal and newborn animals*

\begin{tabular}{lccc}
\hline \multicolumn{1}{c}{ Sample } & $n \dagger$ & $\begin{array}{c}\text { Angiotensinogen mRNA } \\
\text { (\% of reference 138 d } \\
\text { fetus) } \ddagger\end{array}$ & $\begin{array}{c}\beta \text {-Actin mRNA } \\
\text { (\% of reference } \\
138 \mathrm{~d} \text { fetus }) \S\end{array}$ \\
\hline Fetus (60 d) & 2 & $0.37(0.007)$ & $1.06(0.17)$ \\
Fetus (90 d) & 2 & $0.47(0.12)$ & $1.31(0.65)$ \\
Fetus (118 d) & 5 & $0.63(0.26)$ & $1.44(0.53)$ \\
Fetus (138 d) & 4 & $0.97(0.15)$ & $0.91(0.29)$ \\
Newborn (7 d) & 3 & $0.78(0.07)$ & $0.91(0.33)$ \\
\hline
\end{tabular}

* Values are means (SD).

$\dagger n$ equals number of livers studied.

$\ddagger$ Changes in angiotensinogen mRNA as a function of age were statistically significant $(p=0.016)$ using one-way analysis of variance.

$\S$ Changes in $\beta$-actin mRNA were not significantly different $(p=0.37)$ using one-way analysis of variance.

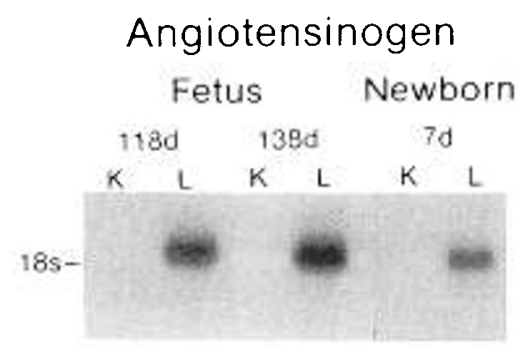

Fig. 3. Autoradiograph of Northern blot analysis of fetal and newborn liver $(L)$ and kidney $(K)$ RNA. Ten- $\mu$ g aliquots of total cellular RNA were fractionated by gel electrophoresis and transferred to a nylon filter. The Northern blot was hybridized with ${ }^{32}$-labeled antisense angiotensinogen RNA. The hybridized filter was exposed to film for $5 \mathrm{~d}$.

\section{Angiotensinogen}

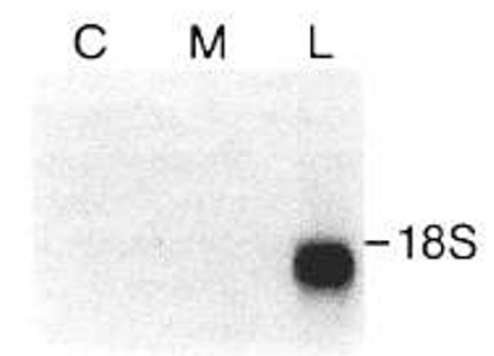

Fig. 4. Autoradiograph of Northern blot analysis of adult male kidney cortex $(C)$, kidney medulla $(M)$, and liver $(L)$ RNA. Ten- $\mu$ g aliquots of total cellular RNA were fractionated by gel electrophoresis and transferred to a nylon filter. The Northern blot was hybridized with ${ }^{32} \mathrm{P}$ labeled antisense angiotensinogen RNA. The hybridized filter was exposed to film for $3 \mathrm{~d}$.

hepatic angiotensinogen were specific rather than a reflection of generalized changes in fetal liver gene expression.

In an effort to investigate the possibility that other tissues may also be important sources of angiotensinogen during fetal life, we compared angiotensinogen mRNA samples from fetal and newborn liver and kidney. Northern blot analysis of liver and kidney RNA from fetal sheep (118 and $138 \mathrm{~d}$ gestational age) and newborn lamb are shown in Figure 3. We were unable to detect angiotensinogen mRNA sequences in any of the kidney RNA samples at the three ages studied. Even with prolonged exposure to film ( $7 \mathrm{~d}$, data not shown), no hybridized material was apparent in the kidney samples.

Additionally, we also determined if angiotensinogen mRNA is found in kidney of mature sheep. Total cellular RNA was isolated from kidney cortex and medulla of an adult male and probed for angiotensinogen. Northern blot analysis (Fig. 4) shows 
that angiotensinogen sequences were undetectable in both kidney cortex and medulla.

\section{DISCUSSION}

Through Northern hybridization, we have shown that angiotensinogen mRNA sequences are present in fetal sheep liver at least by $60 \mathrm{~d}$ of gestation. The amount of angiotensinogen mRNA per unit of total RNA increases in the fetal liver with increasing gestational age. After birth, the amount of angiotensinogen message appears to decrease slightly. We have not determined if increases in liver angiotensinogen during gestation parallel increases in circulating angiotensinogen and plasma angiotensin II concentration.

Changes in angiotensinogen gene expression in liver and other tissue in response to a variety of physiologic and hormonal stimuli have been studied in adult animals (16-20). However, there is presently no data available regarding factors regulating angiotensinogen gene expression during fetal life. Inasmuch as angiotensinogen mRNA expression undergoes a maturational process, it is likely that gene regulatory mechanisms also undergo maturation.

The results of our study suggest that the ontogeny of angiotensinogen may differ between species. The development of angiotensinogen mRNA in the sheep appears to be quite different from development in the rat. This may be due to maturational differences between the sheep and rat at the time of birth, inasmuch as the newborn lamb is much more mature at birth than is the rat. Liver angiotensinogen mRNA sequences appear in the neonatal rat about $24 \mathrm{~h}$ after birth (6). This may be similar to the increase in angiotensinogen mRNA that we have seen between 118 and $138 \mathrm{~d}$ gestation in fetal sheep.

We were unable to detect the presence of angiotensinogen mRNA in either fetal, newborn, or mature sheep kidney. This was unexpected, inasmuch as angiotensinogen mRNA sequences have been demonstrated in the kidney of adult rats $(21-24)$. The relative quantity of renal angiotensinogen mRNA to liver angiotensinogen mRNA ranges from $5(25)$ to approximately $50 \%$ (26) per unit of total RNA in rat. Gomez et al. (6) reported the presence of angiotensinogen mRNA in total RNA extracts from fetal rat kidney; however, angiotensinogen $m R N A$ was detectable at low levels in fetal rat liver only after poly $\mathrm{A}^{+}$selection of liver RNA. This suggests a relatively high abundance of angiotensinogen mRNA in fetal rat kidney compared with fetal rat liver. Our current methodology allows us to measure 100 -fold differences in sequence abundance (27); therefore, if angiotensinogen mRNA is present in the sheep kidney, it is less than $1 \%$ the amount of angiotensinogen mRNA found in sheep liver.

\section{REFERENCES}

1. Siegal SR, Fisher DA 1980 Ontogeny of the renin-angiotensin-aldosterone system in the fetal and newborn lamb. Pediatr Res 14:99-102

2. Robillard JE, Nakamura KT 1988 Neurohormonal regulation of renal function during development. Am J Physiol 254:F771-F779
3. Broughton PF, Lumbers ER, Mott JC 1974 Factors influencing plasma renin and angiotensin II in the conscious ewe and its foetus. J Physiol (Lond) 243:619-636

4. Symonds EM, Furler I 1973 Plasma renin levels in the normal and anephric fetus at birth. Biol Neonate 23:133-138

5. Campbell DJ, Habener JF 1986 Angiotensinogen gene is expressed and differentially regulated in multiple tissues of the rat. J Clin Invest 78:31-39

6. Gomez RA, Cassis L, Lynch KR, Chevalier RL, Wilfong N, Carey RM, Peach MJ 1988 Fetal expression of the angiotensinogen gene. Endocrinology 123:2298-2302

7. Jennings JJ, Crowley JP 1972 The influence of mating management on fertility in ewes following progesterone PMS treatment. Vet Rec 90:495-498

8. Robillard JE, Weitzman RE 1980 Developmental aspects of the fetal renal response to exogenous arginine vasopressin. Am J Physiol 238:F407-F414

9. Chirgwin JM, Przybyla AE, MacDonald RJ, Rutter WJ 1979 Isolation of biologically active ribonucleic acid from sources enriched in ribonuclease. Biochemistry 18:5294-5299

10. Lynch K, Simnad V, Ben-Ari E, Garrison J 1986 Localization of preangiotensinogen messenger RNA sequences in the rat brain. Hypertension 8:540543

11. Cleveland DW, Lopata MA, MacDonald RJ, Cowan NJ, Rutter WJ, Kirschner MW 1980 Number and evolutionary conservation of alpha and beta-tubulin and cytoplasmic beta and gamma-actin genes using specific cloned cDNA probes. Cell 20:95-105

12. Kisker CT, Perlman S, Bohlken D, Wicklund B 1988 Measurement of prothrombin mRNA during gestation and early neonatal development. J Lab Clin Med 112:407-412

13. Melton DA, Krieg PA, Rebagliati MR, Maniatis T, Zinn K, Green MR 1984 Efficient in vitro synthesis of biologically active RNA and RNA hybridization probes from plasmids containing a bacteriophage SP6 promoter. Nucleic Acids Res 12:7035-7056

14. Lehrach H, Diamond D, Wozney JM, Boedtker H 1977 RNA molecular weight determinations by gel electrophoresis under denaturating conditions, a critical re-examination. Biochemistry 16:4743-4751

15. Snedecor GW, Cochran WG 1967 Statistical Methods. The Iowa State University Press, Ames, IA, pp 258-296

16. Kageyama R, Ohkubo H, Shigetado N 1986 Induction of rat liver angiotensinogen mRNA following acute inflammation. Biochem Biophys Res Commun 129:826-832

17. Kalinyak JE, Perlman AJ 1987 Tissue-specific regulation of angiotensinogen mRNA accumulation by dexamethasone. J Biol Chem 262:460-464

18. Sernia C, Clements JA, Funder JS 1989 Regulation of liver angiotensinogen mRNA by glucocorticoids and thyroxine. Mol Cell Endocrinol 61:147-156

19. Iwao H, Fukui K, Kim S, Nakayama K, Ohkubo H, Nakanishi S, Youichi A 1988 Sodium balance effects on renin, angiotensinogen, and atrial natriuretic polypeptide mRNA levels. Am J Physiol 255:E129-E136

20. Ingelfinger JR, Pratt RE, Ellison K, Dzau VJ 1986 Sodium regulation of angiotensinogen mRNA expression in rat kidney cortex and medulla. Clin Invest 78:1311-1315

21. Ohkubo H, Nakayama K, Tanaka T, Nakanishi S 1986 Tissue distribution of rat angiotensinogen mRNA and structural analysis of its heterogeneity. J Biol Chem 261:319-323

22. Campbell DJ, Habener JF 1986 Regional distribution of angiotensinogen messenger RNA in rat adrenal and kidney. $J$ Hypertens 4:S385-S387

23. Fried TA, Simpson EA 1986 Intrarenal localization of angiotensinogen mRNA by RNA-DNA dot-blot hybridization. Am J Physiol 250:F374-F377

24. Ingelfinger JR, Pratt RE, Ellison K, Dzau VJ 1986 Angiotensinogen mRNA is expressed in both rat renal cortex and medulla. J Hypertens 4:S434-S436

25. Dzau VJ, Ellison KE, Brody T, Ingelfinger J, Pratt RE 1987 A comparative study of the distribution of renin and angiotensinogen messenger ribonucleic acids in rat and mouse tissues. Endocrinology 120:2334-2338

26. Hellman W, Suzuki F, Ohkubo H, Nakanishi S, Ludwig G, Ganten D 1988 Angiotensinogen gene expression in extrahepatic rat tissues: application of a solution hybridization assay. Naunyn Schmiedebergs Arch Pharmacol 338:327-331

27. Perlman S, Jacobsen G, Moore S 1988 Regional localization of virus in the central nervous system of mice persistently infected with murine coronavirus JHM. Virology 166:328-338 